\title{
Taxing Nigeria's Emerging Digital Economy: A Vital Buffer to an Ailing Economy
}

\author{
Abiola Adebanjo \\ Dele Falana \& Co.
}

Think of Jumia or Amazon in retail, Uber or Bolt in ride sharing, Coursera or Udemy in your quest for knowledge and you will understand what digital services entails. Digital has to do with our gadgets, while economy refers to money or trade. These two otherwise disconnected terms are now yoked by a click necessitating new taxing rules across borders.

We use search engines, online advertising channels, e-commerce sites and subscription platforms daily. While some of these services are provided by Non-Resident Companies (NRC's) that are not taxed, their resident competitors are easy targets for tax purposes.

With the digitisation of business solutions and cyberisation of the workplace, the Finance Act 2019 has finally replaced the concept of Permanent (PE) Establishment with Significant Economic Presence (SEP) in line with global trend.

It appears a digital economy will in a matter of time replace the traditional economy and if not rightly taxed will result in consequential losses for some countries. Nigeria should be ready for the next phase of taxation.

Keywords: digital economy, digital taxation, e-commerce, permanent establishment, significant economic presence, non resident company

\section{INTRODUCTION}

With over 196 million internet connections across different devices, ${ }^{1}$ improving broadband penetration, ${ }^{2}$ and an expected 75 billion dollar revenue by $2025,{ }^{3}$ Nigeria is yet to see corresponding income in taxes when compared to the volume of digital transactions it records. Nigeria is one of the two dominant Business-to-consumer (B2C) markets in Africa alongside South Africa. It's ratio of tax to GDP has been hovering around 5\% - 6\% since 2017 till 2020, well below the continental average and a cause for concern. ${ }^{4}$

Notwithstanding that the traditional economy is stealthily giving way to a digital economy, a traditional tax system ${ }^{5}$ characterised by fairness, adequacy, simplicity, transparency and administrative ease is still desirable. Digital tax administration should engage the taxpayers, empower the employees, optimise operations, and transform the services of the tax administrator. ${ }^{6}$ The tax system in a digital economy is not entirely new but an adaptation of extant rules. Another hurdle for this new taxation concept is the duty of ensuring that digital taxation is effected in a sustainable manner. ${ }^{7}$ 
It is a truism that a cash-light economy will aid a digital economy and ought to be pursued by incentivising financial inclusion rather than the unnerving charges in the name of Stamp duty which the Nigerian government has set up as a digital tax. ${ }^{8}$ The regressive tax has dissuaded banking which is key to having a cash-light or cashless economy that the government of Nigeria has been trying to achieve for about a decade now.

The principle of Permanent Establishment (PE) has finally given way due to a dematerialised significant presence which brings with it virtual economic activities. Nigeria's 2019 Finance Act has now captured foreign businesses doing business in Nigeria for tax purposes by replacing the PE concept with that of Significant Economic Presence (SEP). ${ }^{9}$ It has been suggested that the concept of PE itself is not the problem of taxing the digital economy in developing countries and rather that the problem is that of ambiguous principle of profit attribution. ${ }^{10}$ This implies that even with a PE, NRCs can still shift their profits with aggressive tax planning.

An NRC is deemed to have SEP and taxable in Nigeria if it grosses 25 million naira or any of its equivalent in any currency in revenue from digital contents, data transmission or sale of goods or other services, agency services or using a Nigerian domain name among others. ${ }^{11}$ It is quite inadequate to state what constitutes SEP but fail to specify how profit will be attributed to the NRC in focus. Also, the threshold of 25 million naira revenue would mean any NRC with less revenue would be deemed to have insignificant economic presence. Whether this is intended to forgo the tax on profits of such NRCs remains to be seen in the enforcement procedure of the FIRS (Federal Indland Revenue Service). It has been suggested that what constitutes SEP should be wider than what is captured and should include transactions paid for via payment cards issued by a Nigerian financial institution or transactions whose ultimate payments are made by Nigerian financial institution; cases where the location of the users and consumers at the time of transaction is in Nigeria; or the location of the person making the demand and consuming the goods or service is in Nigeria. ${ }^{12}$ In pursuance of this, there is a Federal Inland Revenue Service tax circular on the filing of tax returns by NRC's under the provisions of the Nigerian law.

Corporate taxes are not determined by looking at the income and expenditure of corporate organisations. The tax man would need to weed out what it perceives not to be incurred wholly, exclusively, and necessarily as business costs from what is presented by a taxpayer as deductible expenses. The case of NRCs becomes more complicated as it may be difficult to attribute certain profits to the jurisdiction seeking to tax the NRC even with an established SEP. There are different methods for apportioning profits to NRCs, some of which include, the fractional apportionment method ${ }^{13}$ the Modified residual profit split method, ${ }^{14}$ and the distribution-based approaches, among others. The OECD is still trying to fashion a unified method of profit allocation applicable and acceptable for all. This may be an onerous task however.

A digital economy will in fact aid base erosion and profit shifting strategies which itself has been a case study for several years in the international tax system, however the prospects of a digital economy is far reaching for a country like Nigeria. Especially as she consumes more of foreign goods and services and thereby spend more abroad. Digital taxation offers her an avenue to properly tax what is spent abroad if Nigerians cannot provide such goods or service. Moreover, taxation is the core of a country's sovereignty. ${ }^{15}$ No country is immune to Base erosion and Profit shifting and there is a reason why Action 1 of the Base Erosion and Profit Shifting (BEPS) Action Plan addresses the challenges of the digital economy. Profit shifting and Base erosion denies would-be tax jurisdictions of tax revenues. Tech giants have adopted the Double Irish with Dutch Sandwich tax avoidance technique to deny tax revenues over the years.

The idea behind leveraging on technology to provide goods and services is to be able to enhance productivity. You reach more clients, reduce costs, improve security, save time, explore new markets, and improve capacity. These are enough reasons to use technology for modern business. If the economy becomes more digital and digital economy becomes the main economy, there would necessarily be a need to reassess the taxing landscape. The recent pandemic movement-restrictions also brought to fore the need for a digital way of life. Imagine what life would have been without technology during a lockdown and we all have to wait for the postman tomorrow to know what is going on?

The digital economy is only an enabler and most items ordered online still have to be physically delivered, others are delivered digitally and likely to be digitally consumed, with the exception of items 
such as 3D printable files. For now it appears digitalised products will likely evade payable custom duties. They also bring about the challenge of revenue mischaracterisation. Is the value paid for digital products regarded as business profits or royalties? The current trend is to treat them as business profit if the buyer has no licence to share it, and as a royalty where the buyer can share them.

The use of e-filing ${ }^{16}$ in the Nigeria tax space is acknowledged as an important step towards digitising tax administration, but it is just an aspect of the entire process and equally utilised by many other countries. Nigeria's e-filing is supported by services like e-Registration, e-Stamp Duty, e-TaxPayment, e-Receipt, and e-TCC. However, we need to further this milestone by adopting e-Accounting, e-Match, e-Audit, and eAssess among others to deepen tax administration. Providing a digital infrastructure will not in itself cure the digital challenge in tax administration as there must be complementary provision of the processes and background technical ability required to ensure compliance, filling the tax gap, cross border complementary provisions and double taxation reliefs. Not to mention the ability of taxpapyer to adapt to it.

While tax is a matter of a State's exclusive legislative competence, its cross border implications is that it requires application of international law and in federated unions the application of local State laws for inter-state transactions. Extant international tax framework is inadequate because of changes and advancement in technology and its effect on national taxes. However, equal treatment of taxable persons across different jurisdictions requires international cooperation. The Organisation for Economic Cooperation and Development (OECD) particularly and the United Nations (UN) have been at the forefront of ensuring fair taxes across board especially with the OECD's BEPS project and its various model tax conventions. These if sustained will bring about a global fair tax regime.

\section{WHAT IS A DIGITAL ECONOMY?}

A digital economy refers to the economic activities that result from everyday online connections among people, businesses, devices, data, and processes. The backbone of the digital economy is connectivity which means growing interconnectedness of people, organisations, and machines that results from the internet, mobile technology and internet of things. ${ }^{17}$ It is also known as internet economy or web economy. However, no country runs a totally digital economy as it is only a relatively new aspect of our economy which supports traditional economy in many countries, though some are substantially close to being a fully digital economy.

It is said that Nigeria's mobile economy reach is just $1 \%$ of its potentials and needs critical infrastructure right away. ${ }^{18}$ A digital economy will improve our Internet of things (IoT) projections, as it will aid transportation, education, health, mobile money, commerce, among others. The flip side for tax administrators is that digital transactions or services have taxing implications as they are also digital records for the transactions as well. A digital economy is the convergence of communication, computing and information. It aids a faster and digital delivery of goods and services via networks, platforms or channels and basically includes; a digitally ordered service, platform enabled services, or a digitally delivered transaction. It is a fact that digital currencies are no legal tender but the future of a digital economy may change this assertion.

The number of internet users in Nigeria continues to soar yearly, increasing by millions every year. Ecommerce usage also increases everyday due to the trust which some ecommerce companies have gained over time especially by offering a 'Pay on Delivery' (POD) option to customers and ensuring customer satisfaction on orders placed. The downside to the POD option which has also affected these companies is that orders placed may suffer rejection at the point of delivery for some reasons, ranging from valid to ridiculous. This is however a cost that has brought more confidence to the industry today. Amazon is also an example to look at when trying to achieve customer satisfaction in ecommerce.

Running a digital economy is internet driven, it is thus imperative to attain a national broadband coverage that is affordable and reliable. This requires investment over time and may require incentivising the providers of telecommunication, driving down spectrum license fee and right of way (RoW) charges. Digital inclusion has always been touted as a factor for economic development. Nigeria's year-on-year growth in digital inclusion shows potential for a robust digital penetration for the future. The tripod of availability, affordability and application should be consciously managed to take advantage of the digital 
evolution for economic development. There is a need for the government to rethink its stance on digital infrastructure for public access that will guarantee connectivity and improve our technological advancement. The digital economy value chain consists of firms operating within an eco-system who delivers content and applications to consumers and businesses alike. ${ }^{19}$ The firms in this value chain will play a critical role and should not be constrained by policies or regulations. This will stimulate growth and ensure broader internet penetration. While state governments usually have the authority to regulate infrastructure in their domain, it is suggested that these regulations should not stifle growth and should be objective. The earlier we can get internet for all, the better for our economy.

Online transaction may be e-commerce or e-government and they refer to a wide range of online business and administrative activities for good, products and services. It emphasises transactions where interactions are electronically done rather than physically. It may be B2C, B2B, B2G, C2C or even C2G. The turn of the century has meant the internet taking over how business is conducted from immediate or remote locations. Tax administrators must move with this tide if they want to remain at work and generate tax income as everyone looks for an avenue to arrange their tax affairs within the lacuna created by the law.

\section{FROM 'PERMANENT ESTABLISHMENT' TO 'SIGNIFICANT ECONOMIC PRESENCE'}

The concept of Permanent Establishment (PE) in international taxation was developed under German law, particularly in Prussia in the second half of the $19^{\text {th }}$ century. It was as a result of the need to prevent double taxation between municipalities in Prussia and the old German States. ${ }^{20}$ It however became globally accepted after the League of Nations intervention into the 'evils of double taxation' at the end of World War by publication of the Model Convention for the Prevention of Double Taxation of 1928. The concept of PE is that until an enterprise of one State has a permanent establishment in another State it should not properly be regarded as participating in the economic life of that other State to such an extent that the other State should have taxing rights on its profits. This requires two thresholds of a fixed place through which the business of the enterprise is wholly or partly carried on, and, a person acting on behalf of the foreign enterprise and habitually exercising an authority to conclude contracts in the name of the foreign enterprise. These two conditions must be concurrently evident before a PE can be said to exist.

Article 5 (1) of the Double Taxation relief Order between Nigeria and Netherlands for example provides that a PE means a fixed place of business through which the business of an enterprise is wholly or partly carried on. According to its paragraph (2) it can include a place of management, a branch, an office, a factory, a workshop, a mine, an oil and gas well, a quarry or any other place of extraction of natural resources. This creates various degrees of presence.

The digital economy has necessitated a tweak of the PE concept. However, the Significant Economic Presence (SEP) concept seem to be more prominent of the known numerous variants some of which are the Significant Digital Presence, ${ }^{21}$ taxable digital presence, and the virtual PE. They are measured by different thresholds such as the number of digital contracts remotely concluded, number of site visitors, level of consumption of digital goods, and number of active users of online tools in some other cases. ${ }^{22}$ The use of a bandwidth or 'bit' tax has also been proposed. ${ }^{23}$ A deemed PE may apply where an enterprise without having a fixed place in a state has persons acting on behalf of the enterprise. This may be referred to as an agency PE. Other options are to replace PE with significant presence and the creation of a withholding tax on digital transactions.

Though Significant Economic Presence (SEP) has more acceptance, it is by no means a guaranteed model as the evolution of digital economy continues to bring new intrigues and results which were not forethought. Tax planning experts will continue to take advantage of the loopholes in our tax laws regardless of our tax base theory. Attempts to avoid a taxable presence by NRC should be expected and this is why it is important that we take a dive into the digital economy and learn the possible trends as soon as we can so as to be able to prevent through policy and laws constructive erosion of the tax base. 


\section{TAX CHALLENGES FACING AN EMERGING DIGITAL ECONOMY}

One way to look at the challenges of the digital economy is to see them as opportunities for growth. While we are looking to make the economy digital, some are ahead trying to make taxation fully automated and digital. This would mean taxing an event real time or near real time and not having to wait till the end of the year to audit. Make no mistake, the potential cost of errors in a digital tax administration is a cause for concern. It can affect the revenue derivable, or damage the reputation of the administration, and even dampen the morale of taxpayers. ${ }^{24}$

Currently, the cumbersome nature of government businesses in Nigeria including filing taxes can putoff a willing taxpayer. Simple processes which ought to be managed personally have to be outsourced because of bureaucracy. A bulk of new business entrants are persons between the age of $20-40$ and they are not ready to waste time just to pay taxes. If tax payments services are available online it would bring in more revenue. A company that is non-operational but has to file a monthly zero VAT returns for example would rather forget about filing it if the cost of filing is measured in terms of resources. Making this seamless with deigital platforms is desirable.

Tax audits of corporate organisations take years to be concluded presently. This is outside the possibility of the organisation objecting to the audit or its amendment, or the filing of a Notice of Appeal among others before the tax tribunal determines what the tax should be. With our slow legal system, this means tax payable for the current year may be paid after 5 years it has become due. Tax administrators spend years in ascertaining what ought to have been paid for in the preceding year of assessment thus making it difficult to project. Moving to e-audit with real-time tools will solve a lot of problems for both the tax payer and the tax administrator, this however requires full disclosure from the taxpayer. This is the same way countries have to agree on exchange of information to combat tax evasion.

It is suggested that public service providers should adopt the data-only-once principle to capture citizens into the tax net. A National Identity Number (NIN) for personal use or Taxpayer Identification Number (TIN) for corporate persons would do the magic and make it less rigorous for citizens to adopt a digital way of life. This means citizens have a particular set of identity numbers that will make it easier to track tax payments and other government services. India for example has been able to rely on use of a permanent account number to expand the reach of tax payers,${ }^{25}$ and reduce the tax gap by gradually expanding its reach to the hard-to-tax group.

Another challenge for tax administrators is aggressive profit shifting strategies which is essentially tax planning and not unlawful. An organic legal system will tackle the challenges of profit shifting with laws and policies, this will require a resolute legislature and responsive tax administrator / institution to rescue the situation when needed. Cross border taxation of personal income will also challenge the digital journey as nothing is predictable yet. Residence based tax principle for Personal income tax should still be applicable despite the fact that the internet is creating more digital workers and online freelancers who transcend diverse borders to provide services. They may be resident in India, US, or Netherlands and provide service for Germans. The payments made to these nationals are taxed by those countries nevertheless, but the Germans paying should still have the right to charge a withholding tax on such payments if there is full disclosure which laws should demand. Estonia has developed the e-resident principle. E-residency does not however mean tax residency. ${ }^{26}$ Neither does it confer the right to live in the country or offer citizenship rights. It allows non-residents to access services such as company registration, banking, payment processing, and taxation through the use of a smart card.

Tax gap is the difference between tax collected by government and what is actually collectible. This gap in Nigeria is widened by mistrust, corruption, poor tax administration, and unwillingness on the part of some taxpayers. While the attainment of proper digitalised tax system will require professionalism on the part of the tax administrator, it also requires variants of technology, the technical capacity of the people to administer, managing of tax risks by the taxman, financial resources, and communication.

With increasing teledensity and e-commerce reach most tax liable transactions will continue to be rooted in the traditional economy and partly in the digital economy. This is understandably as a result of our uneducated population with astute and deep business interests on one hand and the upwardly mobile 
young population on the other. These challenges in the digital economy are not peculiar for the Nigerian state. Being a new challenge coming on the heels of the issue of Base erosion and profit shifting, it is yet to have a certain formula as various countries have responded as they deem fit.

The challenges to be faced are of various types including technology gap, technology distrust/fear, government transparency, tax compliance, tax evasion, tax avoidance, tax corruption, dishonesty, income non-disclosure, voluntary compliance, and data privacy/breach among others.

\section{VAT AND E-COMMERCE IN THE DIGITAL ECONOMY}

A digital economy should not pose much problems for VATable Business to Business (B2B) transactions, but for trans-border Business to Customer (B2C) VATable transactions especially remotely executed businesses, challenges will arise as a result of one of the parties not being a collecting agent for VAT purposes as required by law.

For some transactions, the cost of collecting VAT may exceed the VAT receivable and therefore render the pursuit of the payable VAT uneconomical. ${ }^{27}$ It is the position of the OECD ${ }^{28}$ that the non-collection of VAT from such imports could bring an unfair competitive pressure on domestic retailers who are required to charge VAT on their sales. This may not necessarily be so in all cases as imported good will still be liable for cost of importation while the domestic purchaser will only pay VAT. The cost of a low item value may eventually rise because of the cost of import. Regardless, a formula to ensure that VAT is paid on either offline or online commerce with inbuilt mechanisms for charging at source is needed.

Attempts by the FIRS to charge tax on online payment of goods and services has been criticised in some quarters but cannot be said to be an illegitimate attempt at taxation, it was the validity of the execution that knocked it off. Charging VAT on online sales in this case will affect both local and international sellers as the e-commerce sector has been successful over the years. The plan of the IRS was to appoint banks as collecting agents, whereas the law makes a reseller a collection agent. Financial institutions are not in the business of selling goods but providing financial services. The appointment of banks as collection agent for online transaction would have created a mess not in the appointment but in its execution. It is apparent especially for local transactions in instances where goods and services already have VAT prices included that they will suffer needless further taxation just because they are paying online. So if a buyer accesses an online store and buys items with VAT inclusive prices but chooses to pay via his card, a further charge of VAT on such purchase because he is buying online will amount to multiple taxation. Attributing the duty of collection of VAT to banks without a legal framework would have been amounted to administrative recklessness in ensuring tax compliance.

The other option to this automated charge on payment maybe self-assessment which Nigerians are wont to avoid. It may therefore be necessary for foreign entities doing business in Nigeria remotely to be mandated to be incorporated as a separate entity if they want their services to be accessed by Nigerians as required by the Companies and Alliend Matters $\mathrm{Act}^{29}$ and provide returns of VAT charged its consumers. It is a fact that digital footprints of payment are easy to trace especially if banks are mandated to give a report of payments to enable audit of the VAT payments. African countries are wont to be slow to implement change and not expected to change soon with administrative duties. But there is a need for nonresident digitalised businesses to be capture for VAT registration and income tax purposes. Section 10 of the VAT Act already requires registration for VAT by non-resident companies. If this can be done remotely without stress, then we can have more VAT income from remote e-commerce activities.

For local online purchases which are also high in volume, the Federal Inland Revenue Service can request for report or information on payments received by merchants through card payments. Since foreign merchants are not collecting agents until registered for VAT it would be safe to conclude that their prices are not VAT inclusive and may be subjected to VAT payment at the point of receiving their payment from the local purchaser. A legal framework through which all foreign payments for e-commerce activities will be chargeable for VAT may be put in place. Using a threshold of sale volume to charge tax or relying on other options such as the UK's Digital Sales Tax or India's Equalisation levy which are surcharges of between $2 \%$ to $6 \%$ of gross revenue may be considered. 
It is not all gloom and bleak for VAT on ecommerce, the results that technology will afford in detecting and preventing tax fraud are far reaching. Technology tracks, reduces costs and provides actionable data. A digital economy will bring about efficient tax audits and ensure that errors are few if not eliminated. In a digital economy VATable goods will be assessed and VAT payable appropriated real time. Services by professionals will require self-reporting or tracking of payments to such persons if the economy is cashlight. Accountability is assured with online transactions as they are recorded quite well for references unlike cash payments which may give room to manipulations. It is the submission of a scholar that government should encourage players in the digital industry and not scare them with this tax but should tread carefully in its implementation. ${ }^{30}$ It's been suggested also that a way out for cross border electronic transactions is to levy a withholding tax at the source country to avoid any case of VAT exclusion or SEP mischaracterisation. ${ }^{31}$

\section{STATES GOVERNMENTS' ONLINE SALES TAX IN THE DIGITAL ECONOMY}

The collection of tax in a federal state is a critical aspect of the federated units. Nigeria's federal system is deficient in several ways and needs to evolve to enable a proper taxing landscape. As presently constituted, components States would not be able to charge Sales tax for inter-State transactions conducted online. This is because item 62 of the 1999 Constitution of Nigeria makes law-making on inter-state commerce exclusive to the Federal Government.

The U. S. Supreme Court has ruled expectedly that in a Federal Union, subnational State governments may require online retailers to collect Sales tax with the courts judgment in South Dakota vs Wayfair. In so doing the court ruled that a State government does not need to have a retailer or have a physical presence or employees in a State before the state could require collection of Sales tax. This is federalism as it ought to be, wherein the component states are not appendages of the federal government. However, it is agreed that it is the Constitution that assigns taxing power and this should not be contemplated since the Nigerian constitution reserved inter-state commerce legislation for the Federal Government.

Sales tax is not foreign to the Nigerian taxing landscape and indeed has had a chequered history. As a consumption tax, it is imposed on consumptions. The Produce Sales tax Law of Lagos State of 1959 and the Ogun State Sales tax law of February 1982 are the very first entrants, but it was the latter that was first legally tested through the Attorney General of Ogun State v Alhaja Ayinke Aberuagba's 's2 case. Lagos State levies tax on consumption via the Sales tax law CAP S3, Laws of Lagos State 2003 and the Hotel Occupancy and Restaurant Consumption Tax Law 2009. Some merchants in the hospitality industry particularly had queried the rationale for subjecting their clients to a VAT and the HORC citing double taxation even though it appears to be multiplicity of tax. This has however been laid to rest as the component States, Lagos in this case has the right to charge a Sales tax notwithstanding the federal VAT. In the case of A. G. Federation v A. G. Lagos $^{33}$ it was settled that the Lagos State government had the powers to impose taxes via the Hotel Occupancy and Restaurant Consumption Law of Lagos and that the law was validly made.

Once the possibility of double or multiple taxation is resolved in favour of the State government, the only outstanding problem for States would be identity management to effectively track digital footprints. Regardless of the provision of the exclusive list however, States governments can still charge consumption taxes but on intra-state transactions that originate and are destined for consumption locations within the state. As such if A is resident in Oyo State and intends to buy a mobile phone from Jumia, whose office is in Lagos, he may avoid paying a Sales Tax if the Lagos office sends the mobile phone directly to him in Oyo State. This may be impracticable for Jumia however, as it will likely have a local presence in Oyo State through whom A will eventually get the phone. The taxman cannot deny or disregard the Permanent Establishment which Jumia uses as a vehicle to achieve distribution, even though Jumia sent the mobile phone from outside the State to A. This brings about a nexus and therefore becomes an intra-state commerce liable to be taxed. Common forms of Sales tax nexus that affects ecommerce businesses are physical presence, economic, affiliate, economic threshold, or web cookies nexus. ${ }^{34}$ 
Apparently, while technology aids digital taxation and the digital economy, it can also enable fraudulent activities. Mobile money platforms is an important part of Uganda's digital economy and was recently defrauded leading to a suspension of mobile money services between two providers in the country. Hackers broke into the system of a $3^{\text {rd }}$ party provider whose business is to translate money from banks into mobile money. But whether we like it or not the digital economy will soon take over and component states of the federation will long for a share of the new economy. However, to benefit from this, States must ensure compliance with low enforcement costs. This will require urging businesses or local companies to register with the State IRS for audit purposes, and with the current inability of the Nigerian State to account for its citizens, this might be an uphill task. The enforcement of the Hotel Occupancy and Restaurant Consumption Law for example is still plagued with inaccuracies from the taxpayers. The use of an electronic cash register may be enforced to ensure accuracy in record keeping by merchants.

\section{INTERNATIONAL TAXATION PERSPECTIVES AND IMPLICATIONS}

To capture taxable persons into the tax net, it is important to first ascertain and profile your potential taxpayers and in case of corporations to determine that it has significant economic presence for liability purposes. There are various methodologies to achieve this due to the fact that digital taxation is of recent history. It is important to ascertain that the value created by the activities of consumers of digital services is recognised in determining where those business profits are to be taxed. While a push for global reforms are necessary, we should be prepared to adopt unilateral solutions to the problems we have at any turn in our journey to tax digital services while minding the extant obligation we have in our tax treaties.

The international tax framework on digital tax of corporations tend to emphasise that taxes ought to be paid to the country in which value generating activities and risks are controlled. It suggests that another country should not have the powers to tax profits that a UK business generates from a product that is designed in the UK, manufactured in the UK, marketed in the UK and then sold remotely to that country. ${ }^{35}$ While the creation of value is of importance, the source of income jurisdiction should also be considered. It is doubtful if this submission would still be right if the product was sold in its entirety to another country? The UK business must have advertised its product to the buying country, it has sold its product to that country and generated profit from that country. It means that the UK business in such scenario would have gained some economic advantage from the other country and if we are to follow the basic precepts for taxation, there are public goods like security, infrastructure and rule of law among others which the company benefits from in that country. Tax liabilities may be subject to the international DTA's in place, but the business is a legal entity liable to taxation and if a Nigerian is taxed, why not a UK company making profits from Nigeria. Developing countries particularly should not be hoodwinked into abandoning their rights to tax as many economic activities will be going digital in the near future and if we fail to tax those activities, we might as well be selling ourselves cheap.

Nigeria for example has for long not taken digital taxation seriously. In recent times, twitter has become a focal point due to government seeing it as amplifying the voices of Nigerians and has been pencilled down for heavy taxation. There is an extant taxing legistalation with supporting rgulations which haven't been utilised because of intituttional regulatory deficiencies over the years leading to loss of revenue.

\section{THE DIGITAL TRANSFORMATION JOURNEY}

Transforming from analogue to digital is always a challenge everywhere even in developed countries. Taking a hint from the successes of Nigeria's Integrated Personnel and Payroll Information System which was a biometric based application used to weed out ghost workers from our Civil Service, it is obvious that technology would curb a lot of corrupt practices in our tax system. Applications like this are able to detect

fraud, prevent it, and track everything on it while giving actionable intelligence. So also will a digital tax infrastructure in real time capture tax liabilities and assess taxable activities. The taxing landscape is fraught with so many issues which digitisation would not resolve overnight but will steadily improve. Particularly 
in terms of the receivables. However, the Nigerian government has to invest to get such results. Some of the important investments required are discussed.

\section{Technology and Infrastructure}

Going digital means leveraging on technology to do certain things. It is commendable that certain aspects of our tax administration are already online. The FIRS has shown clearly that tax administrators can benefit from technological advancement. Certain services of the FIRS are already digital including efiling, e-Registration, e-Stamp Duty, e-Tax Payment, e-Receipt, and e-TCC. Even with these, the FIRS is more challenged now with the need to play catch up with the rising global trends of taxation especially with a digital economy. While the technology and infrastructure needed by the tax administrator is of utmost importance, accessing the services by the public means the access to technology by the taxpayer. While security is considered in doing so, allowing everyone access it with affordable internet broadband services is imperative.

\section{Self-Compliance Methodology and Strategy for Data Analysis}

Bearing in mind that there are different segments to taxpayers that are in the tax gap and the need to capture them into the tax net, the tax administrator needs to develop a robust plan to encourage selfcompliance and make self-assessment easier. The bulk of the working population are now those who fit into the computer age as we call them. If they are certain that they can easily assess their liabilities, pay it without going back and forth, and know that the tax paid will work for them, they will pay tax. There may be a need to incentivise taxpayers with discounts and access to certain government facilities, platforms or programmes.

\section{Law and Policy Making}

While the legal framework for chargeable tax may remain, that of administration will need tweaks. Digitalising tax administration will necessarily require modern administrative procedures with legislations that recognises the need to sustain confidence, privacy of data and terms of use. The fundamental thing is that a tax must be by law, collection is administrative and may not necessarily need new laws, but the National tax Policy should be reviewed to align itself with current trends. The policy should also include strategic goals, targets and KPIs for specific terms.

A digital economy must be matched by a digital tax administration. Though we are yet to achieve a digital economy, we must be prepared for it through change management, training and education. ${ }^{36}$ This will ultimately simplify tax administration, aid forecast, trend analysis, impact policy formulations and reduce the likelihood of human interference which might lead to compromising a tax administrator. According to the last referenced author, the digital transformation will simplify compliance, eliminate fraud and error while also allowing easier refund because of the transparency it will have. It certainly will bring about reduced time of operations and cost among others.

\section{TAXPAYER'S DATA PROTECTION IN A DIGITAL ERA}

A digital economy is data driven and every taxpayer need to know that their personal data will not be breached. They equally want a guarantee of high privacy and security. Digital footprints can be traced and data stolen online. The use of electronic solutions as e-assessment, e-audit, and e-filing leaves data for miners if they have access to the portals and this would mean the taxpayer becomes more uncomfortable with electronic or digital services. A loss of data belonging to a taxpayer could cause panic especially for the rich as the taxpayer is open to some real or imagined financial risk. The financial standing of the subject is also made public as such.

While providing customised service to a taxpayer with his data is good, the value derived from it is negligible if compared to the effect of a data breach. It is not impossible to identify a user by a string of numbers or code while the personal data is encoded, but service providers want to create a trusting and endearing relation by getting to know who the customers are. When your bank sends you a customised 
birthday text message to celebrate you, one feels joyful from the use of such data but the flipside is that data breach may be costly. This is why some people even in developed countries have avoided digital recognition all their lives.

The National Information Technology Development Agency (NITDA) realising that businesses are now moving online and using personal data for variety of purposes and intending to protect the data of individuals released the Nigeria Data Protection Regulations (NDPR) in January 2019. This regulation adopted enforcement standards for companies that processes personal data of data-subjects. The regulation ultimately intends to protect the privacy rights of individuals by giving citizens control over the use of personal data. It aims to safeguard the right of natural persons with regards to processing of personal data, and to foster safe conduct of transactions involving the exchange of personal data. There are guidelines for data processing by public institutions who come into contact with data as a matter of direct interaction or in line with its statutory or administrative duty. There must be a legitimate basis for processing the data of anyone,${ }^{37}$ though most public institutions would usually have a basis for doing so under public interest. As such since it is unlawful not to pay tax, the tax authority may process my data under the public interest basis. A taxpayer will have the legal obligation by virtue of the PITA to furnish data to the taxman, but as a data processor or controller, the taxman must deal with the data reasonably to ensure it is not compromised. The principle of lawfulness state that data controller must have legal ground to process personal information and be clear, open and honest about how they use data subjects' personal data.

The tax administrator is to ensure that all necessary procedures and measure are in place to safeguard personal data form theft, malware, accidental loss or unauthorised usage. There are sanctions in case of data breaches. However the NDPR did not provide in clear terms if these sanctions are applicable to public agencies who are guilty of a data breach. 'The Guidelines for the Management of Personal Data by Public Institutions in Nigeria' hereafter 'the Guidelines' is not to be treated as a separate document in terms of Data protection rules, but must be read together with the Regulation itself. When this is done, public institutions who fail to comply with Data Protection Rules would be liable for their actions.

\section{CONCLUSIONS}

Why should we focus on maximising taxation in a digital economy? Apart from the fact that developing countries including Nigeria are becoming a source of revenue for data driven services which are mostly untaxed or poorly taxed, the Nigerian government also launched a Digital Economy Policy and Strategy in November 2019 with emphasis on digitizing the provision of public services. It is therefore imperative to prepare for a digital transformation of our tax administration to be at par with the global digital economy permeating our economies slowly to aid stability and the economic growth of the country.

To benefit from a digital economy, Nigeria must invest in science and technology, align its law and policy to international best practices, further encourage cashless transactions, leverage tax information exchange agreements, and make the most of its human resources. The challenges of the digital economy cannot be wished away and must be resolved over time. This includes perceived insecurity and low level of digital skills / literacy among others.

For us to fit well into the digital economy since there is a need to evaluate and project into what will obtain in the near future, what will Artificial Intelligence (AI) bring to our homes ${ }^{38}$ care homes and offices, how will 3D printing of goods disrupt the economy digitally? ${ }^{39}$ How will robots displace humans and render the human resources department lean and how can data protection be assured?

Accelerating the digital transformation of tax administration requires expertise of diverse professionals and we need to look beyond the immediate before we make policies. The start may be rigorous but once we are able to generate actionable data insights, future projections will be easier to monitor and track.

Getting Nigerians to do more self-assessment and reporting will be a mirage until the perception of the government as corrupt improves. The digital economy provides an avenue for us as a developing country to leapfrog certain stages treaded by developed nations and attain digital maturity by simply replicating their successes. Tax agencies will embark on a journey to stay on course and will do well to design clear 
vision and strategic focus for the future, invest in dynamic management capabilities, and sustain a continuing education programme for its employees.

Digital taxation will be beneficial in the long run for the tax administrator and taxpayer himself. In Estonia for example, electronic tax claims and digital signatures have facilitated tax management and lowered bureaucracy. ${ }^{40}$ In a country where $99 \%$ banking transactions are done online and $95 \%$ of tax declarations are online a digital economy and tax administration is surely looking good. ${ }^{41}$ It takes three clicks and 30 seconds to file your income tax returns there. It is very important for Nigeria to start small now and be in a position to scale up on its successes when the digital economy blooms. Nigeria needs to start with a wholesome cash-light system then gravitate towards capturing all online transactions to attain a cashless economy. It is said that when everyone pays tax, then everyone will pay much less tax as the tax burden will not be on the few taxpayers in the tax net.

Nigeria will need to learn a lot from countries like China, Brazil, and Finland among others as countries who have taken digital taxation very seriously. If well marshalled Nigeria's taxation should suffice for its needs. Kenya in its drive towards digitalisation is improving the affordability of mobile ownership in line with its vision on National Broadband Strategy and the country's Vision 2030. ${ }^{42}$

Financial data and technical expertise of tax administrators would be invaluable in the digital era. Investing and proficiency in these tools should be prioritised now as the cost of recovering tax should be way less than the tax recovered over time. Data and analytics particularly will aid the audits of companies as real time data will reduce time and energy expended in tax recovery.

It is recommended that any tax of a digital nature sought to be imposed must be a progressive tax. Attempts to impose any further surcharges in the name of taxing social media should be restrained as it would not only imply gagging free speech as popularly envisaged but will also affect usage of digital services that may improve the digital economy.

Non Resident companies (NRC's) have for long avoided paying tax and still avoid doing so. While the likes of Google and Uber as NRCs have local subsidiary and pays tax in Nigeria, Amazon has no physical presence in Nigeria but carries on business while not registered for taxation. ${ }^{43}$ It is also alleged that twitter has no tax history despite raking in million from Nigeria over the years. Nigeria seems to be ahead of them in terms of the provision of Section 78 of CAMA which requires NRC's wishing to do business in Nigeria to form a local subsidiary but has not been enforcing this provision except in the oil industry where FIRS has been very active. As a rule, ${ }^{44}$ a NRC engaged in petroleum operations is assessed and charged as if it were resident in Nigeria. Nigeria needs to start taxing the digital economy now that it is still at its early stage especially since foreign businesses have a large market presence with digital services. Data appears to be the new gold, and data related activities will continue to bring it revenue for everyone who leverages on it very well.

\section{ENDNOTES}

1. Subscribers Statistics https://www.ncc.gov.ng/statistics-reports/subscriber-data\#quarterly-subscriberoperator-data. Accessed the 10th October 2020, at 20:45

2. There is still low penetration in the rural areas. Having access to SIM cards is only tied to holders identity for security reasons. However the affordability of telephony services needs to be reviewed to improve the digital economy culture .

3. Nigeria Digital Economy Diagnostic report. http://documents1.worldbank.org/curated/en/387871574812599817/pdf/Nigeria-Digital-EconomyDiagnostic-Report.pdf Accessed the 10th October 2020, at 21:10.

4. Temitope Kolade, (2019) Nigeria's unchanging tax to GDP ratio: An intrusive appraisal. mondaq.com/Nigeria/tax-authorities/848314/nigeria39s-unchanging-tax-to-gdp-ratio-an-intrusiveappraisal. Accessed 10th October 2020 at 21:21

5. Ade Ipaye, (2014) Nigerian Tax Law and Administration: A Critical Review, 2014, London, ASCO Prime Publishers. 
6. PwC \& Microsoft (2018), Digital transformation of tax administration, http://info.microsoft.com/rs/157GQE-382/images/Digital\%20Transformation\%20of\%20Tax\%20Administration\%20White\%20Paper.pdf, Accessed 10th October 2021 at 21:30

7. Ogochukwu Isiadinso and Emmanuel Omoju (2019), Taxation of Nigeria's Digital economy: Challenges and prospects. https://www.mondaq.com/nigeria/tax-authorities/810276/taxation-of-nigeria39s-digital-economychallenges-and-prospects Accessed the 10th October 2020, at 22:05

8. Wole Obayomi (2020), FIRS provides clarifications on administration of stamp duties in Nigeria. https:/home.kpmg/ng/en/home/insights/2020/07/firs-provides-clarifications-on-administration-of-stampduties-in-nigeria.html Accessed the 10th October 2020, at 22:10

9. This necessarily meant amending Section 13 of the CITA which requires companies to be taxed on their corporate income when they have physical presence in the country.

10. Mustapha Ndajiwo, (2020) The taxation of the Digitalised Economy: An African Study. International Center for Tax and Development, Institute of Development Studies

11. Companies Income Tax (Significant Economic Presence) Order, 2020

12. Micheal Ango \& Samuel Ibrahim, (2020) Taxing the digital economy based on Significant Economic presence: A Guide for the implementation of the Finance Act, 2019. Business Day Newspaper, Tuesday 17 March 2020,pg. 9

13. This involves the determination of the amount of profits subject to the new taxing rights without making any distinction between routine and non-routine profits.

14. This method will allocate to market jurisdictions a portion of an NRC's groups' non-routine profit that reflects the value created in markets that is not recognized under the existing profit allocation rules.

15. Thomas Wilde, (2008) National Tax measures affecting foreign investors under the discipline of International Investment treaties, Heinonline.org 102 Am. Soc'y Int'l L Proc 51,

16. The use of standard electronic form for filing tax returns

17. Deloitte, What is digital economy? Unicorns, transformation and the internet of things. Available online at https://www2.deloitte.com/mt/en/pages/technology/articles/mt-what-is-digital-economy.html. Accessed 24th of October 2020, at 9:12

18. Jane Egerton-Idehen, (2020) Country Manager, Avanti Communications. Interview on Channels Television, Tech Trends.

19. Prof. Raul Katz, (2015) The impact of taxation on the digital economy, Paper presented at the 15th ITU's Global Symposium for Regulators. Libreville, Gabon 9 to 11 June 2015.

20. Skaar, A. A., (1991) The history of the concept of PE. Kluwer Law and Taxation Publishers.

21. This concept is seen as a way to ring-fence digital activities and leave out other economic activities, thus the preference for 'Significant economic presence' or even 'significant presence'.

22. OECD, (2014) Addressing the Tax Challenges of the Digital Economy, OECD/G20 Base Erosion and Profit Shifting Project, OECD Publishing. Available on http://dx.doi.org/10.1787/9789264218789-en, Accessed 24th of October 2020, at 9:30.

23. ibid

24. Jingan C. S. Grimshaw and Ors., (2017) Testing and implementing Digital tax administration. https://www.elibrary.imf.org/view/IMF071/24304-9781484315224/243049781484315224/ch05.xml?language $=$ en\&redirect=true. Accessed 24th of October 2020, at 10:07

25. Arvind Panagariya, (2008) India: The Emerging Giant, OUP, UK.

26. Evelyn Liivamagi, (2017) How do e-residents pay taxes? e-estonia.com/how-do-e-residents-pay-taxes/ Accessed 24th of October 2020, at 10:13.

27. In such situation the imported good is below the de minimis threshold for customs duties.

28. Supra footnote 22, pg. 136

29. Section 78 of CAMA, 2019

30. Taiwo Oyedele, PwC Nigeria, (2019) How the proposed VAT on online transactions will affect you. http://www.mondaq.com/nigeria/sales-taxes-vat-gst/842898/tax-101--how-the-proposed-vat-on-onlinetransactions-will-affect-you?login=true. Accessed 24th of October 2020, at 10:34

31. Supra, footnote 12 , pg 146

32. 19851 NWLR pt. 3, pg. 395

33. Unreported Suit No SC. 340/2010, delivered on 19th July 2013

34. Annie Musgrove, (2020) US Sales tax for eCommerce: How to comply. https://quaderno.io/blog/us-salestax-for-ecommerce-how-to-comply/ Accessed 24th of October 2020, at 10:29 
35. Corporate tax and the digital economy: Position paper (2017)

https://assets.publishing.service.gov.uk/government/uploads/system/uploads/attachment_data/file/661458/c orporate_tax_and_the_digital_economy_position_paper.pdf Accessed 24th of October 2020, at 11:04

36. Supra footnote 6, pg 18

37. This may be by consent, contractual obligation, vital interest, public interest, legal obligation or lawful ground

38. The owners of an AI will mostly be foreign technological companies

39. Will the license to print designs by purchasers qualify to be royalties which is subjected to withholding tax or profits on sale subject to profits taxation

40. David Campbell and Georg Hanschitz, Digitalization of Tax: Epistemic tax policy, (2018) https://www.researchgate.net/publication/321766946_Digitalization_of_Tax_Epistemic_Tax_Policy

Accessed 24th of October 2020, at 10:44

41. ibid

42. Mobile taxation in Kenya: Accelerating Digital development (2020) Available online at gsma.com/mobiletaxation-in-kenya Accessed 24th of October 2020, at 10:44

43. Supra, footnote 10, pg 31

44. Section 25 of the PPTA, Cap P13 